EDUCATION

Research, Innovotion and Solutions on-line ${ }^{6}$

\section{Electronic Journal of Research}

in Educational Psychology

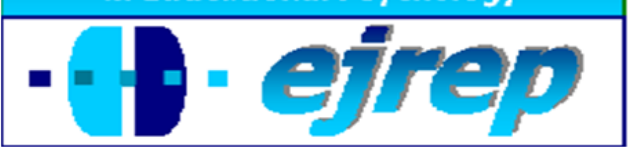

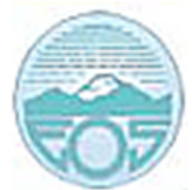

Editorial EOS

\title{
A Comparison of Problem Behavior Profiles in Turkish Children with AD/HD and non-AD/HD Children
}

Selda Ozdemir

Special Education Department, Gazi University, Ankara

Turkey

Correspondence: Selda Ozdemir. Gazi University, Gazi Education Faculty, Special Education Department, Gazi Egitim Fakultesi, Ozel Egitim Bolumu L Blok Zemin 11 Teknikokullar. Ankara 06500. Turkey. Email: seldaozdemir@gazi.edu.tr, seldaunaldi@yahoo.com

(C) Education \& Psychology I+D+i and Editorial EOS (Spain) 


\begin{abstract}
Introduction. There is an increasing number of studies describing the symptoms of ADHD among school-age children in western cultures. Yet, studies on children with ADHD living in non-western cultures are limited. Thus, the purpose of this study was to compare problem behavior profiles of Turkish children with AD/HD and non-AD/HD children.
\end{abstract}

Method. A total of 49 children with and without AD/HD were included in the study.

Problem behaviors of participating children were measured using the Child Behavior Checklist (CBCL) Turkish form.

Results. Analysis of the CBCL revealed that Turkish children with AD/HD were in the clinical range for problem behavior compared to non-AD/HD children. Turkish parents of children with $\mathrm{AD} / \mathrm{HD}$ reported high rates of aggressive behavior, attention problems, and rule breaking behavior.

Conclusion. Overall, these results suggest similar findings on the characteristics of children with ADHD. That is, Turkish children with AD/HD have been found to display clinical levels of problem behaviors compared to their typically developing peers. These results were discussed in the light of the available literature and recommendations for practice were provided.

Keywords: Attention deficit hyperactivity disorder; problem behavior; aggressive behavior; culture; social problems; Child Behavior Checklist.

Received: 08/04/09 Initial Acceptance: 08/22/09Ｄefinitive Acceptance: 01/11/10 


\section{Comparación de perfiles de conducta problemática en niños turcos con TDAH y niños sin TDAH}

\section{Resumen}

Introducción: En la cultura occidental existe un incremento en el número de estudios que describen los síntomas del Trastorno de Déficit de Atención con Hiperactividad (TDAH) entre los escolares. No obstante, los estudios sobre TDAH entre niños de culturas no occidentales son limitados. Así, el propósito de este estudio es comparar perfiles de problemas de comportamiento en niños turcos con Déficit de Atención/Déficit de Hiperactividad (DA/DH) y aquellos que no lo sufren.

Método: Un total de 49 niños con y sin DA/DH participaron en este estudio. Los problemas de comportamiento de los niños fueron evaluados mediante la versión en turco de la Child Behavior Checklist (CBCL).

Resultados: El análisis de los resultados del CBCL refleja que los niños turcos con DA/DH se situaban en los rangos clínicos en comparación con los niños sin DA/DH. Los padres de los niños con los trastornos señalaron tasas altas de comportamiento agresivo, problemas de atención y problemas con el cumplimiento de normas.

Discusión y Conclusiones: En general, los resultados apuntan similitudes en las características de los niños con TDAH. En este sentido, los niños turcos con TDAH presentan niveles clínicos en cuanto a problemas de conducta en comparación con los otros niños que no tienen este trastorno. Los resultados se discuten bajo el marco de la literatura disponible y se proporcionan recomendaciones para una práctica adecuada.

Keywords: Attention deficit hyperactivity disorder; problem behavior; aggressive behavior; culture; social problems; Child Behavior Checklist.

Recibido: 04/08/09 Aceptación Inicial: 22/08/09 Aceptación Definitiva: 11/01/10 


\section{Introduction}

Attention-Deficit/Hyperactivity Disorder (AD/HD) is a diagnostic label given to children who have significant problems in sustained attention, organization, impulse control, and regulation of activity level in response to situational demands (APA; Diagnostic and Statistical Manual of Mental Disorders, 2000; Rowland, Umbach, Stallone, Naftel, Bohlig, \& Sandier 2002). As a result of these difficulties, children with $\mathrm{AD} / \mathrm{HD}$ experience severe pervasive impairment in social relationships, academic progress, cooperative social-exchange skills, stress resistance, self-control of aggressive impulses, and self-esteem (Barkley, 2006; Stormont, 2001; Treuting \& Hinshaw, 2001). Researchers estimate that at least $3 \%-5 \%$ of school-aged children have AD/HD in the U.S. (DSM-IV, 2000; Barkley, 2001; Barkley, 2006; Peterson, Pine, Cohen, \& Brook, 2001). Similar prevalence rates have been found in Turkish school-age population suggesting that most classrooms may very well have at least one child with $\mathrm{AD} / \mathrm{HD}$ (Ersan, Dogan, Dogan, \& Sumer, 1994).

One area of tremendous difficulty for children with $\mathrm{AD} / \mathrm{HD}$ is in their social relationships with peers and adults (Barkley, 2006; Hinshaw \& Melnick, 1995; Hoza, Pelham, Dobbs, Owens, \& Pillow 2002; Hoza et al., 2005; Stormont, 2001). The failure to develop and maintain positive peer relationships is consistently emphasized in the literature as one of the core problems of the disorder (Barkley, 2006; Landau, Milich, \& Diener, 1998). Studies have shown that children with the disorder display more aggressive, irritable, hostile, excessive, immature, proactive, intense, non-compliant, and emotional behaviors (Hinshaw \& Melnick, 1995; Mikami \& Hinshaw, 2003; Stroes, Alberts, \& Van der Meere, 2003). According to Barkley (2006), children with AD/HD appear to perceive social and emotional cues from others in a more limited and inaccurate fashion, as if they were not paying as much attention to emotional information provided by others. In a recent study, Justicia and colleagues (2006) suggested that attention problems when combined with high temperament and impulsiveness may heighten overall risk for antisocial behavior. It appears that developmentally inappropriate levels of inattention, hyperactivity and impulsivity when combined with aggression and higher 
levels of emotional intensity, may overwhelm a child's capacity to self-regulate and interfere with the age appropriate emotional and behavioral control. Indeed, research has documented that children with $\mathrm{AD} / \mathrm{HD}$ often display more disruptive, intrusive, noisy, and disorganized behaviors (Hinshaw \& Melnick, 1995; Hodgens, Cole, \& Boldizar, 2000; Maedgen \& Carlson, 2000; Mikami \& Hinshaw, 2003; Stroes, Alberts, \& Van der Meere, 2003). Research to date therefore seems to suggest that much of the disturbance in the social interactions appears to stem from the effects of a child's impulsive, domineering, intense, and emotional behaviors. In a study, Erhardt and Hinshaw (1994) examined the influence of naturalistic social behaviors and nonbehavioral variables on the development of peer status in unfamiliar boys with AD/HD and typically developing peers. From the first day, the boys with $\mathrm{AD} / \mathrm{HD}$ displayed clear differences in their social behavior. The children with $\mathrm{AD} / \mathrm{HD}$ were overwhelmingly rejected. The researchers concluded that social rejection of children with $\mathrm{AD} / \mathrm{HD}$ developed after only brief periods of peer exposure.

In general, childhood peer problems stand out as strong predictors of enduring social and academic difficulties (Mannuzza, Klein, Bessler, Malloy, \& LaPadula, 1998; Klein \& Mannuzza, 1991; Parker \& Asher, 1987; Young, 2002) and are considered among the most intervention-resistant domains of AD/HD (Hinshaw, 1992; Melnick \& Hinshaw, 1996). Such children are more likely to develop conduct disorder, to participate in more delinquent or illegal acts as adolescents, and to engage in greater substance experimentation and eventual dependence and abuse than are purely hyperactive or impulsive children (Barkley, Fischer, Edelbrock, \& Smallish, 1991; Biederman et al., 1996; Bush \& Ladd, 2001; Ladd \& Burges, 2001; Mannuzza, Klein, Bessler, Malloy, \& LaPadula, 1998; Parker \& Asher, 1987; Young, 2002). Indeed, follow-up studies suggest that early peer problems not only indicate concurrent difficulties for the child, but also represent a significant "at risk" marker for later emotional and behavioral disturbance (Landau \& Milich, 1990; Landau, Milich, \& Diener, 1998). Even those children with $\mathrm{AD} / \mathrm{HD}$ who are monitored into adolescence and found to be free of psychiatric disorders appear to have some social problems, such as significantly less community and school activity involvement (Mannuzza, Klein, Bonagura, Konig, \& Shenker, 1988). Thus, even 
if long-term outcome measures did not reveal subsequent adjustment problems, one is left to wonder if children with $\mathrm{AD} / \mathrm{HD}$ experience the same quality of life as other children (Landau \& Moore, 1991).

Although cultural differences exist in the interpretations of the $\mathrm{AD} / \mathrm{HD}$ symptoms and in expectations on the child behavior, studies conducted in many countries showed that the primary symptoms constituting the disorder appear to be universal (Barkley, 2006). Limited number of AD/HD studies conducted in Turkey mostly investigated epidemiology and neuropsychology (Ercan \& Turgay, 1999; Oncu \& Olmez, 2004) and very few studies explored family psychosocial characteristics (Guclu \& Erkiran, 2005; Gunay-Kilic \& Sener, 2005; Pekcanlar, Turgay, Miral, \& Baykara, 1999). Existing studies of family psychosocial characteristics of children with AD/HD in Turkey dealt with several aspects of families such as parent-child relationship and psychopathology of parents (Aydogdu, 2001; Ozcan, 2002). Summarizing this research, it had generally been found that Turkish parents of all children at all age levels with $\mathrm{AD} / \mathrm{HD}$ report deriving less comfort and value from being a parent, feeling less knowledgeable and skilled, having higher levels of stress and using more authoritarian and negative control than their counterparts whose children do not have an AD/HD (Aydogdu, 2001; Ozcan, 2002). Findings from available studies also showed that most Turkish parents tended to interpret the children as willfully defiant because their child's behavior and performance varies across activities, settings, and time (Aydogdu, 2001; Ozcan, 2002).

There has been a growing body of research showing that children with $\mathrm{AD} / \mathrm{HD}$ display higher levels of problem behaviors and these problems are linked to children's concurrent and long-term social competence and adjustment (Barkley, 2006; Mannuzza, Klein, Bessler, Malloy, \& LaPadula, 1998; Parker \& Asher, 1987; Young, 2002). However, most of these studies were conducted within western cultures; therefore, the literature examining problem behavior profiles of children with $\mathrm{AD} / \mathrm{HD}$ in non-western cultures is scant. Thus, the primary purpose of the present study was to examine differences on the problem behavior profiles of Turkish children with AD/HD and non$\mathrm{AD} / \mathrm{HD}$ children. Based on the findings from previous studies, it was expected that in 
contrast to non-AD/HD Turkish children, Turkish children with AD/HD would exhibit higher levels of problem behaviors.

\section{Method}

\section{Participants}

A total of 49 Turkish children participated in this study. Participants were recruited from public elementary schools located in the capital city of Turkey, Ankara. Eligibility for inclusion in the $\mathrm{AD} / \mathrm{HD}$ group required to be clinically evaluated and diagnosed with $\mathrm{AD} / \mathrm{HD}$. Participants' diagnoses of $\mathrm{AD} / \mathrm{HD}$ were made by University Child Psychiatry clinics located in the capital city of Turkey. All participating children with $\mathrm{AD} / \mathrm{HD}$ were attending child psychiatry clinics for their regular examinations. Yet, children were also attending regular first grade classrooms without receiving any special education services at the time of the study.

Participant children were divided into two groups: Children with AD/HD group included 13 boys ( $M$ age $=8$ years, 5 months, $S D=9$ months) and 12 girls ( $M$ age $=8$ years, 1 months, $S D=10$ months); whereas control group included 12 boys ( $M$ age $=8$ years, 8 months, $S D=7$ months) and 12 girls ( $M$ age $=8$ years, 4 months, $S D=11$ months). There were no significant demographic differences in the demographic characteristics of families of both groups.

\section{Measures}

Child Behavior Checklist (CBCL; Achenbach, 1991). The Child Behavior Checklist (Achenbach, 1991) is a parent questionnaire that covers behavioral and emotional problems of children ages 6 to 18 years. The CBCL has eight subscales (withdrawn, somatic complaints, anxious/depressed, social problems, thought problems, attention problems, delinquent behavior, and aggressive behavior) and two broadband domains: 
internalizing and externalizing problems. The 118-item checklist on the CBCL asks parents to make ratings from 0 to 2 depending on the extent to which a particular statement describes their child. Back translation, bilingual retest method, and pretest field study were done for CBCL Turkish form (Erol, Arslan, \& Akcakin, 1995). The good reliability and validity of the American version of the CBCL were confirmed for the Turkish version (Erol, et al., 1995).

\section{Procedure}

A study participation criterion was developed by the researcher in order to determine the participant children with $\mathrm{AD} / \mathrm{HD}$. According to the study criterion, only Turkish children who had been clinically evaluated and diagnosed with AD/HD prior to the study accepted as candidates to join the study. Clinical diagnosis of $\mathrm{AD} / \mathrm{HD}$ in Turkey was given based on DSM-IV criteria and utilized information from an informant who had known the child.

Teachers and school administrators were contacted through site visits to each school and provided with permission letter explaining the study. In each school, teachers who have students clinically diagnosed with $\mathrm{AD} / \mathrm{HD}$ in their classrooms were explained about the study. Initially teachers contacted with the parents of their students with $\mathrm{AD} / \mathrm{HD}$ and provided the researcher with parents' contact information who agreed to join the study. The researcher called the parents of the children with AD/HD and explained to them that their participation in the study was completely voluntarily.

Next, for the control group, the principals of each participating school were contacted and asked to randomly select teachers from the first through the third grade classes to participate; a lottery drawing technique was used for selecting participating teachers from each school equally distributed among grade levels. Teachers were given detailed information about the study and the CBCL. Once verbal consent was received from the teachers, arrangements were made with parents of typically developing children to give detailed information about the study and the CBCL. All participating parents 
returned the CBCL in one week to the researcher in sealed envelopes without their names.

\section{Results}

\section{Problem Behavior Profiles}

Problem behavior profiles identified using the CBCL Turkish form were analyzed based on cutoff scores determined statistically from psychiatrically healthy and clinical subjects in Turkey. For the externalizing problems, internalizing problems and total problems scores, a T-Score of 63 was considered to be the cutoff score for the clinical range. For eight behavioral syndromes (Anxious/depressed, withdrawn, somatic complaints, social problems, thought problems, attention problems, rule-breaking behavior, and aggressive behavior) a $\mathrm{T}$-score of 70 was considered to be the cutoff score for the clinical range.

The CBCL scores for the children with $\mathrm{AD} / \mathrm{HD}$ and non-AD/HD children are listed in Table 1. The differences in CBCL dimensions between children with AD $\backslash H D$ and non-AD $\backslash \mathrm{HD}$ children were analyzed by using Mann-Whitney U test. Mann-Whitney $\mathrm{U}$ test is used to test for differences between two independent groups on a continuous measure (Pallant, 2007). This test is the non-parametric alternative to the $\mathrm{T}$ test for independent samples. Non-parametric statistics are ideal for use when a study has a small sample (Pallant, 2007). Statistical significance was set up at $<0.05$. The CBCL was completed by one of the participant's guardians, most frequently the mother $(92 \%)$ or father $(8 \%)$ of the study participant. Analysis yielded significant differences between two groups regarding CBCL subscales. The children with $\mathrm{AD} / \mathrm{HD}$ had higher T-scores on the following subscales: aggressive behaviors, attention problems, social problems, rulebreaking behavior, and anxious/depressed (Table 1). In particular, the aggressive behaviors scale was significantly different ( 70.65 versus $56.43, \mathrm{U}=156.24, p=0.0001$ ) from all remaining scales $(p<.05)$. Findings also indicated that two groups did not 
differentiate $(p<.05)$ on withdrawn, somatic complaints, and thought problems subscales (Table 1). Overall scores on the CBCL Syndrome scales of children with AD/HD indicated more abnormality than those of non-AD/HD children (increasing abnormality is indicated by higher scores on the Syndrome scales). Compared to the typically developing children, the $\mathrm{T}$ scores with regard to the externalizing problems $(74.67$ versus $55.42, \mathrm{U}=152.85, p=0.0001)$ and total problems (70.65 versus 55.34, $\mathrm{U}=149, p=$ $0.0001)$ profiles were significantly higher $(p<.05)$ in the children with AD/HD group (Table 1).

Table 1. Socio-demographic and Child Behavior Checklist data of participants.

\begin{tabular}{|c|c|c|c|c|}
\hline & $\begin{array}{c}\text { Children with } \\
\text { AD/HD }\end{array}$ & $\begin{array}{c}\text { Non AD/HD } \\
\text { Children }\end{array}$ & $\mathbf{U}$ & $p$ \\
\hline Girls & 12 & 13 & & \\
\hline Boys & 12 & 12 & & \\
\hline Mean age & 8.1 & 8.7 & & \\
\hline \multicolumn{5}{|l|}{ CBCL } \\
\hline Anxious/Depressed & 63.49 & 55.71 & 240.56 & 0.02 \\
\hline Withdrawn & 53.21 & 51.68 & 262.74 & 0.05 \\
\hline Somatic Complaints & 51.9 & 50.34 & 271.15 & 0.05 \\
\hline Social Problems & 66.34 & 54.33 & 168.43 & 0.0003 \\
\hline Thought Problems & 52.25 & 50.4 & 265.42 & 0.05 \\
\hline Attention Problems & 70.65 & 56.43 & 156.24 & 0.0001 \\
\hline Rule-Breaking Beh. & 58.35 & 52.8 & 256.17 & 0.03 \\
\hline Aggressive Beh. & 68.46 & 54.21 & 155.63 & 0.0001 \\
\hline Internalizing Prob. & 59.68 & 55.72 & 251 & 0.03 \\
\hline Externalizing Prob. & 74.67 & 55.42 & 152.85 & 0.0001 \\
\hline Total Score & 70.65 & 55.34 & 149 & 0.0001 \\
\hline Competence Scales & 37.24 & 35.12 & 263.27 & 0.05 \\
\hline
\end{tabular}

\section{Discussion}

The relation between $\mathrm{AD} / \mathrm{HD}$ and higher levels of problem behaviors has been made explicit by previous research in western cultures (Bagwell, Molina, Pelham, \& Hoza 2001; Barkley, 2006; Stroes, Alberts, \& Van der Meere, 2003). This study 
therefore, examined the differences between problem behavior profiles of children with $\mathrm{AD} / \mathrm{HD}$ and their non-AD/HD peers in Turkish culture. Findings revealed that the problem behaviors of Turkish children with AD/HD were more severe than non-AD/HD children as shown by parents' ratings on the Child Behavior Checklist. In particular, Turkish children with $\mathrm{AD} / \mathrm{HD}$ had more problems in aggressive behaviors, attention problems, social problems, rule breaking behaviors, and anxious/depressed subscales. The findings from this study provide support for an overall pattern of externalizing behavior problems in children with $\mathrm{AD} / \mathrm{HD}$, but no difference of internalizing problems, in comparison to non-AD/HD children.

Specifically, the difference on the aggressive behaviors subscale needs attention. An impressive body of evidence suggests that children with AD/HD display higher levels of aggressive behaviors compared to non-AD/HD children. In fact, researchers have demonstrated that at least one-half of all children with $\mathrm{AD} / \mathrm{HD}$ are known to have comorbid problems with aggressive conduct (Hinshaw, 1987; Hodgens et al., 2000; Maedgen \& Carlson, 2000). Moreover, highly aggressive AD/HD children display severe impairments in the social area, and are strongly rejected by their peers (Gaub \& Carlson, 1997; Hinshaw \& Melnick, 1995; Hodgens, Cole, \& Boldizar, 2000; Landau \& Moore, 1991). Studies have shown that children who are prone to intense emotion, especially negative emotion, and are low in regulation are more likely to engage in externalizing behavior associated with negative emotion (Dodge, Lochman, Harnish, Bates, \& Pettit, 1997). In other words, if children experience strong negative emotions and can not sufficiently modulate their emotion and its' expression, they are more likely to behave in inappropriate ways by externalizing their negative emotions (Eisenberg, et al., 2001; Lemery, Essex, \& Smider, 2002). Supportive of this view, researchers have found that children with $\mathrm{AD} / \mathrm{HD}$ display social behavior that is described as disruptive, controlling, trouble-making, and frequently aggressive (Melnick \& Hinshaw, 1996; Pelham \& Bender, 1982; Whalen \& Henker, 1985). The primary features of AD/HD combined with aggression often interfere negatively with an individual's ability to interact effectively with peers, family members, and others. They demand a great deal of attention from 
others, with their behaviors often being more intense or forceful than the situation requires (Sheridan, 1998).

In general, deficits in aggression and rule breaking behavior may signify one of the primary areas of impairment in $\mathrm{AD} / \mathrm{HD}$ which eventually result in various problems in peer relationships (Barkley, 2006; Gaub \& Carlson, 1997; Hinshaw \& Melnick, 1995; Hodgens, Cole, \& Boldizar, 2000; Landau \& Moore, 1991). Even though a link has been demonstrated between externalizing behavior problems and the presence of social problems in general in western cultures, less work has been done addressing the externalizing behavior problems of children with $\mathrm{AD} / \mathrm{HD}$ living in non western cultures. There is also a great need to move forward in our understanding of how aggressive behavior develops in children with $\mathrm{AD} / \mathrm{HD}$ and how this process may be affected from culture. Information generated by research on children's externalizing problems eventually may yield reformulated interventions for children with AD/HD. Such interventions could foster children's abilities to reinterpret situations cognitively, build awareness of their acts on the negative or uncontrollable aspects of situations, and teach helpful ways of signaling distress (Melnick \& Hinshaw, 1999). Thus, results of the present study suggest that it may be highly beneficial to teach children self awareness of their problem behaviors and how to modulate their expressivity in the context of higher levels of emotional arousal, using role-play and rehearsal to assist children in practicing these skills in the context of emotionally evocative situations. Acquisition of self regulation strategies helps children to trust that behaviors are manageable, controllable, and can be appropriately used; in a sense, children with self regulation strategies feel a sense of control.

Overall, this study extends research on the problem behavior profiles of children with $\mathrm{AD} / \mathrm{HD}$. Specifically, most $\mathrm{AD} / \mathrm{HD}$ studies have been conducted with only male participants, little is known about problem behavior profiles of girls with AD/HD. Results revealed that both Turkish boys and girls with $\mathrm{AD} / \mathrm{HD}$ display more aggressive and rule breaking behavior than their non-AD/HD peers. Replication and extension of the results will be crucial to fully understand the externalizing problem behaviors of children with $\mathrm{AD} / \mathrm{HD}$. However, there are limitations inherent to the study, such as the small number of 
children in each group, which limited the power to detect possible within-AD/HD group differences. Nonetheless, this study confirms a unique CBCL profile identifying behavioral characteristics of children with $\mathrm{AD} / \mathrm{HD}$. Longitudinal studies are needed to assess children with $\mathrm{AD} / \mathrm{HD}$ in order to determine the utility of the CBCL profiles in capturing earlier manifestation of behavioral problems in children with the disorder.

\section{References}

Achenbach, T. M. (1991). Manual for the Child Behavior Checklist/4-18 and 1991 profile. Burlington, VT: University of Vermont, Department of Psychiatry.

American Psychiatric Association, (2000). Diagnostic and statistical manual of mental disorders (4th ed.). Washington, DC: Author.

Aydogdu, A. (2001). Dikkat eksikligi hiperaktivite bozuklugu ve yaygin gelisimsel bozukluk tanisi alan cocuklarin annelerinin bakim gereksinimleri ve cocuklarini algilama duzeyleri [Perceptions of the mothers of children with pervasive developmental disorders and attention deficit hyperactivity disorder on their children and their care needs]. Unpublished master's thesis, Istanbul University, Istanbul, Turkey.

Bagwell, C. L., Molina, B., Pelham, W. E., \& Hoza, B. (2001). Attention-deficit hyperactivity disorder and problems in peer relations: Predictions from childhood to adolescence. Journal of American Academy of Child and Adolescent Psychiatry, 40, 1285-1292.

Barkley, R. A. (2006). Attention-deficit hyperactivity disorder: A handbook for diagnosis and treatment (3rd ed.). New York: Guilford Press.

Barkley, R. (2001). The executive functions and self-regulation: An evolutionary neuropsychological perspective. Neuropsychology Review, 11, 1-29.

Barkley, R. A., Fischer, M., Edelbrock, C., \& Smallish, L. (1991). The adolescent outcome of hyperactive children diagnosed by research criteria . III. Mother-child interactions, family conflicts and maternal psychopathology. Journal of Child Psychology and Psychiatry, 32 (2), 233-255. 
Biederman, J., Faraone, S. V., Millberger, S., Curtis, S., Chen, L., Marrs, A., et al. (1996). Predictors of persistence and remission of ADHD into adolescence: Results from a four-year prospective follow-up study. Journal of the American Academy of Child and Adolescent, 35, 343-351.

Bush, E., \& Ladd, G. W. (2001). Peer rejection in kindergarten: Relational processes mediating academic and emotional outcomes. Developmental Psychology, 37, $550-560$.

Dodge, K. A., Lochman, J. E., Harnish, J. D., Bates, J. E., \& Pettit, G. S. (1997). Reactive and proactive aggression in school children and psychiatrically impaired chronically assaultive youth. Journal of Abnormal Psychology, 106, 37-51.

Eisenberg, N., Cumberland, A., Spinrad, T. L., Fabes, R. A., Shepard, S., Reiser, M., Murphy, B. C., Losoya, S. H., \& Guthrie, I. K. (2001). The relations of regulation and emotionality to children's externalizing and internalizing problem behavior. Child Development, 72, 1112-1134.

Ercan, E. S., \& Turgay, A. (1999). Dikkat eksikligi ve hiperaktivite bozuklugunda beyin goruntuleme calismalari [Brain imagining studies of attention deficit hyperactivity disorder]. Turkish Journal of Psychiatry, 10(2), 134-142.

Erhardt, D., \& Hinshaw, S. (1994). Initial sociometric impressions of attention-deficit hyperactivity disorder and comparison boys: Predictions from social behaviors and from nonbehavioral variables. Journal of Consulting and Clinical Psychology, 62, 833-842.

Ersan, E. E., Dogan, O., Dogan, S., \& Sumer, H. (2004). The distribution of symptoms of attention deficit/hyperactivity disorder and oppositional defiant disorder in school age children in Turkey. European and Child Adolescent Psychiatry, 13, 354-361.

Erol, N., Arslan, L. B., \& Akcakin, M. (1995). The adaptation and standardization of the Child Behavior Checklist among 6-18-year-old Turkish children. In J. A. Sergeant (Ed.). Eunenthydis; European approaches to hyperkinetic disorder (pp. 97-113). Zurich, Switzerland: Fotorotar.

Gaub, M. M., \& Carlson, C. L. (1997). Behavioral characteristics of DSM-IV subtypes in a school based population. Journal of Abnormal Child Psychology, 25, 103-111. 
Guclu, O., \& Erkiran, M. (2004). Dikkat eksikligi ve hiperaktivite bozuklugu tanisi konmus cocuklarin eveynlerinde psikiyatrik yukluluk [Personality disorders in parents of children with attention deficit hyperactivity disorder]. Klinik Psikiyatri, 7, 32-41.

Gunay-Kilic, B., \& Sener, S. (2005). Dikkat eksikligi ve hiperaktivite bozuklugu olan cocuklarda karsit olma karsi gelme bozukluguldavranis bozuklugu es hastalaniminda aike islevleri ve psikososyal degiskenlerin karsilastirilmasi [Family functioning and psychosocial characteristics in children with attention deficit hyperactivity disorder with comorbid oppositional defiant disorder or conduct disorder]. Turkish Journal of Psychiatry, 16(1), 21-28.

Hinshaw, S. P. (1987). On the distinction between attentional deficits/hyperactivity and conduct problems/aggression in child psychopathology. Psychological Bulletin, $101,443-463$.

Hinshaw, S. P. (1992). Externalizing behavior problems and academic underachievement in childhood and adolescence: Causal relationships and underlying mechanisms. Psychological Bulletin, 111, 127-155.

Hinshaw, S. P., \& Melnick, S. (1995). Peer relations in boys with attention deficit hyperactivity disorder with and without comorbid aggression. Development and Psychopathology, 7, 627-647.

Hodgens, J. B., Cole, J., \& Boldizar, J. (2000). Peer-based differences among boys with ADHD. Journal of Clinical Child Psychology, 29, 443-452.

Hoza, B., Pelham, W. E., Dobbs, J., Owens, J., \& Pillow, D. R. (2002). Do boys with attention-deficitlhyperactivity disorder have positive illusory self-concepts? Journal of Abnormal Psychology, 111, 268-278.

Hoza, B., Mrug, S., Gerdes, A. C., Hinshaw, S., Bukowski, W. M., et al. (2005). What aspects of peer relationships are impaired in children with attentiondeficit/hyperactivity disorder? Journal of Consulting and Clinical Psychology, 73 (3), 411-423.

Justicia, F., Benitez, J. L., Pichardo, M. C., Fernandez, E., Garcia, T., \& Fernandez, M. (2006). Towards a new applicative model of antisocial behaviour. Electronic Journal of Research in Educational Psychology, 9, 4(2), 1696-2095. 
Klein, R. G., \& Mannuzza, S. (1991). Long-term outcome of hyperactive children: A review. Journal of the American Academy of Child and Adolescent Psychiatry, 30, 383-387.

Ladd, G. W., \& Burgess, K. B. (2001). Do relational risks and protective factors moderate the linkages between childhood aggression and early psychological and school adjustment? Child Development, 72, 1579-1601.

Landau, S., \& Milich, R. (1990). Assessment of children's social status and peer relations. In A. M. La Greca (Ed.), Through the eyes of child: Obtaining self-reports from children and adolescents (pp. 259-291). Boston: Allyn and Bacon.

Landau, S., Milich. R., \& Diener, M. B. (1998). Peer relations of children with attention deficit hyperactivity disorder. Reading \& Writing Quarterly: Overcoming Learning Difficulties, 14, 83-105.

Landau, S., \& Moore, L. A. (1991). Social skills deficits in children with attention-deficit hyperactivity disorder. School Psychology Review, 20, 235-251.

Lemery, K., Essex, M.J., \& Smider, N.A. (2002). Revealing the relation between temperament and behavior problem symptoms by eliminating measurement confounding: Expert ratings and factor analyses. Child Development, 73, 867-882.

Maedgen, J. W., \& Carlson, C. L., (2000). Social Functioning and emotional regulation in the attention deficit hyperactivity disorder subtypes. Journal of Clinical Child Psychology, 29, 30-42.

Mannuzza, S., Klein, R. G., Bessler, A. Malloy, P., \& LaPadula, M. (1998). Adult psychiatric status of hyperactive boys grown up. American Journal of Psychiatry, 155(4), 493-498.

Mannauzza, S., Klein, R. G., Bonagura, N., Konig, P. H., \& Shenker, R. (1988). Hyperactive boys almost grown up: II. Status of subjects without a mental disorder. Archives of General Psychiatry, 45, 13-18.

Melnick, S. M., \& Hinshaw, S. P. (1996). What they want and what they get: The social goals of boys with ADHD and comparison boys. Journal of Abnormal Child Psychology, 24, 169-185. 
Melnick, S. M., \& Hinshaw, S. P. (1996). What they want and what they get: The social goals of boys with ADHD and comparison boys. Journal of Abnormal Child Psychology, 24, 169-185.

Melnick, S. M., \& Hinshaw, S. P. (1999). Emotion regulation and parenting in AD/HD and comparison boys: Linkages with social behaviors and peer preference. Journal of Abnormal Child Psychology, 28, 73-86.

Mikami, A. Y., \& Hinshaw, S. P. (2003). Buffers of peer rejection among girls with and without ADHD: The role of popularity with adults and goal-directed solitary play. Journal of Abnormal Child Psychology, 31, 381-397.

Oncu, B., \& Olmez, S. (2004). Dikkat eksikligi ve hiperaktivite bozuklugu olan eriskinlerde noropsikolojik bulgular [Neuropsychological findings in adults with attention deficit hyperactivity disorder]. Turkish Journal of Psychiatry, 15(1), 4146.

Ozcan, C. T. (2002). Dikkat eksikligi ve hiperaktivite bozuklugu olan cocuklarin annebabalarinin empati duzeyi ve aile islevlerinin incelenmesi [The emphatic skills and family functioning of parents of the children with attention deficit hyperactivity disorder]. Unpublished master's thesis, GATA, Saglik Bilimleri Enstitusu, Hemsirelik Yuksek Okulu, Ankara, Turkey.

Pallant, J. (2007). SPSS survival manual, $3^{\text {rd }}$ ed. Crows Nest, NSW: Allen \&Unwin.

Parker, J.G., \& Asher, S. R. (1987). Peer relations and later personal adjustment: Are low-accepted children at risk? Psychological Bulletin, 102, 357-389.

Pekcanlar, A., Turgay, A., Miral, S. \& Baykara, A. (1999). Dikkat eksikligi hiperaktivite bozuklugunda aile islevleri [Family functioning in attention deficit hyperaktivity disorder]. Cocuk ve Ruh Sagligi Dergisi, 6(2), 99-107.

Pelham, W. E., \& Bender, M. E. (1982). Peer relationships in hyperactive children: Description and treatment. Advances in Learning and Behavioral Disabilities, 1, 365-436.

Peterson, B. S., Pine, D. S., Cohen, P., \& Brook, J. (2001). A prospective, longitudinal study of tic, obsessive-cumpulsive, and attention deficit-hyperactivity disorders in an epidemiological sample. Journal of the American Academy of Child and Adolescent Psychiatry, 40, 685-695. 
Rowland, A. S., Umbach, D. M., Stallone, L., Naftel, J., Bohlig, M., \& Sandier, D. P. (2002). Prevalence of medication treatment for attention-deficit/hyperactivity disorder among elementary school children in Johnston County, North Carolina. American Journal of Public Health, 92, 231-234.

Sheridan, S. M. (1998). Social skills training for ADHD children S. Goldstein, \& M. Goldstein, (Eds.), Managing attention deficit hyperactivity disorder in children (pp. 592-612). New York: John Wiley \& Sons, Inc.

Stormont, M. (2001). Social outcomes of children with AD/HD: Contributing factors and implications for practice. Psychology in the Schools, 38, 521-531.

Stroes, A., Alberts, E., \& van der Meere, J. J. (20030). Boys with ADHD in social interaction with a nonfamiliar adult: An observational study. Journal of the American Academy of Child and Adolescent Psychiatry, 42, 295-302.

Treuting, J. J., \& Hinshaw, S. P. (2001). Depression and self-esteem in boys with attention-deficit/hyperactivity disorder: Associations with comorbid aggression and explanatory attributional mechanisms. Journal of Abnormal Child Psychology, 29, 23-39.

Young, S. (2000). ADHD children grown: an empirical review. Counseling Psychology Quarterly, 13, 191-200.

Whalen, C. K., \& Henker, B. (1985). The social worlds of hyperactive (ADHD) children. Clinical Psychology Review, 5, 447-478. 